Journal

of Geography

Politics and Society

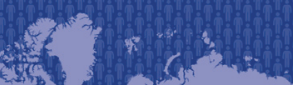

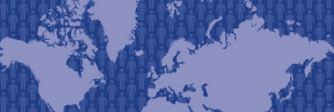
. ind .

\section{Journal of Geography, Politics and Society}

2019, 9(4), 24-34

https://doi.org/10.26881/jpgs.2019.4.03

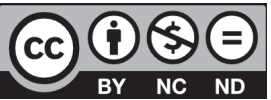

\title{
PROBLEMS OF THE UKRAINIAN LABOR MARKET
}

\author{
Paweł Czapliński (1), Vasyl Dzhaman (2) \\ (1) Department of Economics, Finance and Management, University of Szczecin, Mickiewicza 18, 70-383 Szczecin, Poland, ORCID: 0000-0001-5093-941X \\ e-mail: pawel.czaplinski@usz.edu.pl (corresponding author) \\ (2) Department of Geography, Yuriy Fedkovych Chernivtsi National University, Kotsyubynsky 2, Chernivtsi 58012, Ukraine, ORCID: 0000-0002-9188-3325 \\ e-mail: vasyl_dzhaman@ukr.net
}

\section{Citation}

Czapliński P., Dzhaman V., 2019, Problems of the Ukrainian labor market, Journal of Geography, Politics and Society, 9(4), 24-34.

\begin{abstract}
According to various sources, after 2014 there was a clear decline in GDP and the level of income in Ukraine, which, taking into account the interdependence between economic growth and the condition of the labor market, translated into significant difficulties in the structure of resources and the activity of the local workforce. The source of these difficulties turned out to be not only the price factor, but also non-price factors such as poor protection of employee rights, lack of social protection and social security, as well as payment gridlocks on the employer-employee line. This forced many Ukrainians to sometimes make dramatic decisions about economic emigration, mainly to European Union countries, including Poland. According to various estimates, there are currently 7 to 9 million Ukrainian citizens working abroad who contribute to the development of the economies of other countries. Meanwhile, the Ukrainian labor market is in a very difficult situation. Based on the analysis of official statistical data, an attempt was made to characterize the Ukrainian labor market, its main determinants were outlined and Ukrainians' attitudes towards changes on the domestic labor market were determined. The research used critical literature analysis, statistical description methods, spatial analysis methods and case study method. Based on the conducted analyzes, it was shown that in the years 2010-2017 the Ukrainian labor market was struggling with a number of unfavorable phenomena, which was significantly aggravated by the political crisis at the turn of 2013 and 2014.
\end{abstract}

\section{Key words}

labor market, Ukraine, economic emigration.

\section{Introduction}

The labor market is a complex system of social relations in the area of buying and selling a special type of commodity, which is work. It is worth noting that the work not only has an economic and technical dimension, but also includes political, social, cultural issues at various spatial scales, e.g. local, regional, national, international (Campling et al., 2016; Markova et al., 2019).

It seems that this type of relationship explains the current macroeconomic situation of Ukraine, including a significant part of the problems of the Ukrainian labor market, the main component of which, i.e. the workforce, has not only physical but also psycho-social features, which can play a significant role 
especially in the volatile, unstable and unpredictable environment (Hollinshead, 2019; Moskalenko, Zaporozhets, 2018; Zappalà, Massei, 2011).

It is obvious that the key determinant of every market, including the labor market, will be the price factor related to the mechanism of buying and selling work as a specific form of commodity. The whole mechanism of market regulation through the law of demand and supply also seems to be obvious, which makes this specific type of market similar to other markets (Cartelier, 2017).

However, there are a number of conditions that make the labor market stand out. This applies to, among others labor prices, which, in relation to the human factor, cannot be subject to the usual, sometimes long-term, market game due to biological and social time constraints of employees whose age, needs and capabilities change over time. This seemingly obvious statement can be omitted if there is generational replacement and the sociooccupational structure is not significantly changing. However, it seems that the contemporary global economy, including the globalization processes under way, force transformation of national economies, including national labor markets relatively often, and sometimes also rapidly. In the case of Ukraine, in principle, since it has gained independence, we have been facing significant delays in both diagnosis of the state, restructuring programs and implementations. This means that the development distance of Ukraine to the economies of the European Union is currently several dozen years (Batchenko, Dielini, 2011; Fichter, 2005; Fritz, 2005; Sadova, 2010).

It also results from inefficiency and many mistakes in management, including in strategic management of enterprises, assuming, for example, that the price of the labor force is constant, and therefore the waiting time for a more favorable demand-supply ratio may last for a long time. This erroneous assumption combined with the weakness of national regulations regarding the minimum wage, tariff rates, hours of work, social protection and many other conditions caused a number of dysfunctions of the Ukrainian labor market, including the spread of the shadow economy, corruption and activities on the border of the law, and sometimes even beyond, for example in forest management and wood exports (Czaplińska, Kibych, 2019; Oliskevych, 2015).

One of the features characterising the modern labor market in Ukraine is its segmentation, or rather polarization. It is divided into two main parts: working and non-working, which translates into specificity of economic and social behavior as well as the status, level and stability of income. This division is getting even deeper as result of economic transformation processes launched after 2014. In many areas of economic activity, restructuring processes take place, which results in employee dismissals. The scale of these reductions and the relatively short time to carry them out caused an increase in unemployment and impoverishment of some social groups. In connection with social and political dissatisfaction and the aforementioned legal and administrative weakness of the state, the shadow economy, consisting of informal workers, is developing. Its functioning is dangerous not only for the employees themselves acting on their own and full risk, not only economically, but also for the state because of the lack of coordination and compliance with the development of the official economy. The activities undertaken in this way are usually accepted by local communities due to an economic factor that softens social, ethical and even legal assessments (Markina et al., 2018).

An increasingly popular alternative to the shadow economy is economic emigration, which is usually decided by the unemployed or those who often receive the minimum wage in installments. The most important motive here is the level of wages in the countries of arrival, but in some cases the workplace itself, which allows material security for oneself and one's family. It is also worth noting other determinants of economic trips, i.e. anxiety about the future related to the socio-economic and political situation and high levels of inflation. At the same time, economic emigration is becoming the greatest threat to the Ukrainian economy, especially in the conditions of a low increase in labor productivity. It puts pressure on the level of earnings and the level of social standards, on the profitability of enterprises, etc. Its consequence is economic and social impoverishment of the state, including intellectual one, which can lead to intellectual collapse. Emigration will also negatively impact long-term demographic change (Oliskevych, Tokarchuk, 2018; Dluhopolskyi et al., 2019).

The Ukrainian authorities have started to notice the danger posed by mass economic emigration of citizens for the economic foundations of the country, but the scenarios for limiting emigration are rather pessimistic, despite a number of legislative initiatives and administrative decisions. These actions, however, seem to be overdue and therefore their effectiveness is low. Perhaps this is due to the diagnostic delay, which is based on reliable and timely primary and secondary data. Therefore, there is a need to permanently monitor the behavior of the labor market in a national (central) system as well as in the regional system, because regional labor markets in Ukraine have their specificity. The primary goal 
of monitoring the labor market should be more efficient use of labor resources, creation of attractive employee potential and its commercialization. At the same time, monitoring could contribute to taking effective measures to prevent mass reduction of employment and economic migration. It seems that the existing institutions that are responsible for the labor market do not fulfill the tasks entrusted to them, and ad hoc diagnoses only provoke ad hoc actions of decision-makers, which can be interpreted as the inability to use human resources to develop and strengthen the position of the Ukrainian state (Lehmann et al., 2012; Ryndzak, 2019).

\section{The state of the Ukrainian labor market in the years 2010-2017 (national perspective)}

The situation on the Ukrainian labor market in 20102017 is characterized by several negative phenomena. One of them is the decrease in the number of economically active population aged 15-70 from about 22.1 million to 17.9 million, i.e. by $19.0 \%$ (tab. 1). The dynamics of the economically active population in 2010-2011 remained at a relatively similar level, while from 2012 it adopted a downward trend meaning a slowdown in the development process that continued until the end of the period under review, i.e. until 2017 with a clear, sharp drop in the years 2013, 2014 and 2015 and its inhibition in 2016-2017. Considering the time analysis, the size of the share of the economically active population in the entire population aged 15-70 is similar, with the difference that after 2015 there was a clear increase in the share of this group in the entire population, which may be due to the social mobilization being a response to the complex and difficult internal and external situation of the country, which in consequence led to a rapid deterioration of the material and living conditions of a significant part of the population, but also to the increase in the number of registered unemployed after 2014, especially in the group dismissed at their own request.

Data on the decrease in the number of employed by basic sectors of the economy confirm the general downward trend in total employment with a clear breakthrough in 2013-2014, but at the same time indicate significant cross-sectoral differences (tab. 2). The agricultural sector proved to be the most stable, which confirms its strong position and significant share in the structure of exports and generating GDP. The service sector achieved a similar level of dynamics, which also seems to be predictable, as the service sector usually adopts new market conditions faster. On the other hand, industry and construction, as a result of insufficient capitalization and, as a consequence, low level of technological advancement and weak management practices inadequate to the challenges of the modern world, (lack of formalized internal procedures and manual personnel management, employing cheap labor instead of a smaller number of employees, but supported by modern technologies) lost its employees. The best of them gave up their jobs themselves creating at the same time employment gaps very difficult to fill due to low interest. New specialists did not replace the staff leaving to the private sector or retiring, as they often decided for career abroad.

An important indicator that determines the status of the labor market and the effectiveness of its functioning from the point of view of the state is the unemployment rate, which in Ukraine at the end of 2017 amounted to $9.5 \%$ and was the highest since 2010. In absolute numbers it reflected 1698 thous.

Tab. 1. Population by economic activity (aged 15-70) in Ukraine in the years 2010-2017

\begin{tabular}{|l|r|r|r|r|r|r|r|r|}
\hline \multicolumn{1}{|c|}{ Specification } & \multicolumn{7}{c|}{ Years } & \multicolumn{2}{c|}{2017} \\
\cline { 2 - 9 } & 2010 & 2011 & 2012 & 2013 & 2014 & 2015 & 2016 & 2017 \\
\hline $\begin{array}{l}\text { Economically active } \\
\text { population } \\
\text { [in thous.] }\end{array}$ & 22051.6 & 22056.9 & 22011.5 & 21980.6 & 19920.9 & 18097.9 & 17955.1 & 17854.4 \\
\hline $\begin{array}{l}\text { Dynamics of working } \\
\text { population } \\
\text { 2010=100 }\end{array}$ & 100.0 & 100.0 & 98.8 & 99.7 & 90.3 & 82.1 & 81.4 & 81.0 \\
\hline $\begin{array}{l}\text { Economically active } \\
\text { population in the entire } \\
\text { population [in\%] }\end{array}$ & 63.7 & 64.3 & 64.6 & 65.0 & 62.4 & 60.1 & 62.2 & 62.0 \\
\hline $\begin{array}{l}\text { Employed persons in the } \\
\text { economically active popu- } \\
\text { lation [in\%] }\end{array}$ & 91.9 & 92.1 & 92.5 & 92.8 & 90.7 & 90.8 & 90.6 & 90.4 \\
\hline
\end{tabular}

Source: Statističnij..., 2018. 
Tab. 2. Employed persons (aged 15-70) by economic sectors in Ukraine in the years 2012-2017 [in thous.]

\begin{tabular}{|c|c|c|c|c|c|c|c|c|}
\hline \multirow{2}{*}{ Specification } & \multicolumn{8}{|c|}{ Years } \\
\hline & 2010 & 2011 & 2012 & 2013 & 2014 & 2015 & 2016 & 2017 \\
\hline $\begin{array}{l}\text { Employed persons } \\
\text { Total }\end{array}$ & 20266.0 & 20324.2 & 20354.3 & 20404.1 & 18073.3 & 16443.2 & 16276.9 & 16156.4 \\
\hline $\begin{array}{l}\text { Dynamics } \\
2012=100\end{array}$ & 99.6 & 99.9 & 100.0 & 100.2 & 88.8 & 80.8 & 80.0 & 79.4 \\
\hline \multicolumn{9}{|c|}{ including: } \\
\hline Agriculture & . & . & 3496.0 & 3577.5 & 3091.4 & 2870.6 & 2866.5 & 2860.7 \\
\hline $\begin{array}{l}\text { Dynamics } \\
2012=100\end{array}$ & . & - & 100.0 & 102.3 & 88.4 & 82.1 & 82.0 & 81.8 \\
\hline Industry & . & . & 3345.6 & 3274.8 & 2898.2 & 2573.9 & 2494.8 & 2440.6 \\
\hline $\begin{array}{l}\text { Dynamics } \\
2012=100\end{array}$ & . & . & 100.0 & 97.9 & 86.6 & 76.9 & 74.6 & 72.9 \\
\hline Construction & . & . & 884.9 & 888.8 & 746.4 & 642.1 & 644.5 & 644.3 \\
\hline $\begin{array}{l}\text { Dynamics } \\
2012=100\end{array}$ & $\cdot$ & . & 100.0 & 100.4 & 84.3 & 72.6 & 72.8 & 72.8 \\
\hline Services & . & . & 12627.8 & 12663.0 & 11337.3 & 10356.6 & 10271.1 & 10210.8 \\
\hline $\begin{array}{l}\text { Dynamics } \\
2012=100\end{array}$ & . & . & 100.0 & 100.3 & 89.8 & 82.0 & 81.3 & 80.9 \\
\hline
\end{tabular}

Source: Statističnij..., 2018.

citizens. The total number of unemployed in Ukraine was subject to fluctuations during the period under review, which resultd from many social, economic and political circumstances (tab. 3). One of the most important factors determining the scale of unemployment and its shape was the Ukrainian-Russian crisis, which directly and indirectly affected the number of jobs in the areas, currently beyond the control of the Ukrainian authorities. But the high number of unemployed has a much more fundamental foundation, which results, among others from a commercial policy that has been maintained for years and is mentally fixed. For several years, Ukraine has been and is still an export-oriented country, with low qualifications of employees and a desire to have profitoriented enterprises. This means that the Ukrainian state was not, and perhaps is still not interested in raising salary, because low salaries were seen as the main competitive advantage in the foreign markets. Changing the current course in foreign trade has necessitated a number of changes in the sphere of management, technology, marketing and finance, but their success depends primarily on the employment of more qualified specialists who should be paid much more. However, many questions arise that have a direct impact on the labor market. The key is what happens with existing human resources. Should the staff be freed and new people employed instead, or a deep reorganization based on a wide system of courses and trainings improving or changing the existing qualifications? Secondly, there is the problem as to the level of remuneration, which, despite many central government decisions, still does not meet the expectations of employees. In addition, the remuneration system is not limited only to the financial dimension, but includes a number of additional benefits for both entrepreneurs and the state. In view of the above, it seems reasonable to ask whether there is a real chance to improve working conditions in Ukraine. At the same time, the economic, social and also cultural aspects are important, because the desired evolution require deep mental changes, and these do not occur quickly.

A frequently practiced solution in other countries, including Poland, which seems to be important for the Ukrainian labor market, is to stimulate the entrepreneurial spirit and develop the private sector through individual business activity. The first step in entrepreneurship would be to dismiss one's previous job, often in the public sector (tab. 3). Perhaps that is why this is one of the most important reasons for obtaining a registered unemployed status. Unfortunately, as it results from many studies on the intentions and entrepreneurial attitudes of Ukrainians, the freedom to decide is definitely not enough to start one's own business. Many respondents emphasize that, apart from the lack of sufficient financial resources, they do not have sufficient knowledge and skills, including soft competences (Czapliński, Kib$y c h, 2017)$. Therefore, facing the choice of running own business, raising qualifications and looking for a new job, or looking for new employment abroad, 
Tab. 3. Unemployed in Ukraine (aged 15-70) against the total population in 2012-2017

\begin{tabular}{|c|c|c|c|c|c|c|}
\hline Year & 2012 & 2013 & 2014 & 2015 & 2016 & 2017 \\
\hline Total number of unemployed [in thous.] & 1657.2 & 1576.5 & 1847.6 & 1654.7 & 1678.2 & 1698.0 \\
\hline $\begin{array}{l}\text { Dynamics } \\
2012=100\end{array}$ & 100.0 & 95.1 & 111.5 & 99.8 & 101.3 & 102.5 \\
\hline \multicolumn{7}{|c|}{ Reasons for staying unemployed [in \%] } \\
\hline $\begin{array}{l}\text { dismissal on one's own } \\
\text { request }\end{array}$ & 33.7 & 34.0 & 31.8 & 28.9 & 33.0 & 34.5 \\
\hline economic reasons & 23.4 & 21.2 & 22.3 & 27.8 & 22.4 & 23.2 \\
\hline $\begin{array}{l}\text { no first } \\
\text { job taken }\end{array}$ & 17.0 & 17.3 & 16.7 & 16.4 & 15.6 & 12.2 \\
\hline seasonal work performed & 9.1 & 8.6 & 9.3 & 9.9 & 9.7 & 10.1 \\
\hline others & 16.8 & 18.9 & 19.9 & 17.0 & 19.3 & 20.0 \\
\hline \multicolumn{7}{|c|}{ Total population of Ukraine } \\
\hline Population [in mln] & 45.4 & 45.2 & 42.8 & 42.6 & 42.4 & 42.2 \\
\hline $\begin{array}{l}\text { Dynamics } \\
2012=100\end{array}$ & 100.0 & 99.6 & 94.3 & 93.8 & 93.4 & 93.0 \\
\hline
\end{tabular}

Source: Statističnij..., 2018.

where previous experience may or may not matter, they choose the latter. Dismissal at one's own request is not a final state, but a temporary one, which is supposed to secure and formalize professional status, while giving motivation to look for a job and credibility in the eyes of a future employer.

As it results from the data presented in table 3 , the situation of school graduates is significantly improving, as they seem to be better prepared and adapt faster to the changing conditions of the market game. Their requirements are increasing, but the employee deficit in the market is also growing, hence many employers agree to the conditions, knowing that the Ukrainian labor market, like most European markets, is changing into the "employee market". The reverse situation occurs among seasonal workers usually associated with the agricultural sector. Their periodic activity determines irregular incomes that do not meet basic social needs in difficult socio-economic conditions. Hence the support in the form of benefits resulting from the status of the unemployed person. Such a situation proves not only the low competences of this group, but also the lack of initiative or an idea for own business activity. Results belonging to the group of "others" reasons for unemployment seem interesting, because a very large growing group (4.9\% in 2017) mentioned family reasons there. Their explanation seems ambiguous and complex, but may indicate a division of responsibilities between spouses, one of whom works, often abroad, and the other assumes the fullness of domestic duties by resigning from work. According to estimates, approximately $12 \%$ of Ukrainian households operate in this way. In addition to the devagations on the reasons for remaining unemployed, it is also worth mentioning that the situation on the Ukrainian labor market is affected by the deteriorating demographic situation, whose basic indicators in 2010-2017 such as the total population, age structure, birth rate, life expectancy ratio whether the level of emigration should be considered unfavorable (tab. 3). Their deterioration was associated not only with the standard of living of average citizens, but also with the intentions, attitudes and activity of Ukrainians in the socio-economic sphere, which is often overlooked reducing the cause-andeffect relationship to the economic dimension.

The attitude of many observers towards Ukrainian economic emigration looks similar. Meanwhile, economic emigration should be treated as a natural process of market relations. A long-term process, very complex and not to be perceived only in terms of a threat. It is worth emphasizing that, after all, labor migrations make the labor market more flexible and allow better adjustment of the employment level to changing demand conditions. Therefore, the occurring migration processes should be perceived as a challenge and opportunity, with migration being treated as the result of individual calculation of potential economic profits and costs of possible displacement. However, the non-monetary costs associated with the socio-cultural sphere of individuals and entire societies are also to be taken into account (tab. 4).

In the light of the above, the annual increase in the number of border crossings by Ukrainian citizens should not come as a surprise, nor should the number of permanent residence permits granted in the 
Tab. 4. Border traffic from Ukraine in 2010-2016 - selected elements

\begin{tabular}{|c|c|c|c|c|c|c|c|}
\hline \multirow{2}{*}{ Specification } & \multicolumn{7}{|c|}{ Years } \\
\hline & 2010 & 2011 & 2012 & 2013 & 2014 & 2015 & 2016 \\
\hline $\begin{array}{l}\text { Estimated number of border cross- } \\
\text { ings [in } \mathrm{mln} \text { ] }\end{array}$ & 18 & 20 & 21.5 & 24 & 23 & 23.5 & . \\
\hline $\begin{array}{l}\text { Number of Ukrainian citizens with } \\
\text { the right to reside in EU-28 [in } \\
\text { thous.] }\end{array}$ & 695775 & 749388 & 779953 & 843199 & 883918 & 1027113 & 1113659 \\
\hline $\begin{array}{l}\text { Dynamics } \\
2010=100\end{array}$ & 100.0 & 107.7 & 112.1 & 121.2 & 127.0 & 147.6 & 160.1 \\
\hline $\begin{array}{l}\text { Number of Ukrainian citizens with } \\
\text { the right to reside in EU- } 28 \text { [in } \\
\text { thous.] }\end{array}$ & . & . & . & 217571 & 372346 & 762700 & 1262845 \\
\hline
\end{tabular}

Source: Registration..., nd; Migration..., nd; Migration in Ukraine..., 2016.

$\mathrm{EU}$, which has been dynamically growing in the period under review, which increased by $160 \%$ in seven years. It is worth noting that the actual scale of labor migration from Ukraine is not precisely known, and the available data and knowledge flowing from it fragmentary and stereotypical, which justifies the earlier postulate of the authors about reliable and permanent monitoring of the Ukrainian labor market. It is difficult to prepare and carry out regulatory activities without knowing the state at the starting point.

\section{The state of the Ukrainian labor market in the years 2010-2017 (regional perspective)}

The functioning of the labor market in Ukraine should also be considered in a regional perspective, which is enabled by a significant diversity of demographic and economic potential, socio-cultural differences and the current situation in the east of the country (Niemets et al., 2018).

Average number of employed per 10,000 inhabitants in 2010 amounted to 4350.9 people, but regionally varied, reaching values from 3840.6 in IvanoFrankivsk Oblast to 4,956.4 in the city of Kiev. It often resulted from the production potential accumulated there and its specificity. The socio-political and economic changes that took place over the years 20102017 meant that the number of employed in the vast majority of regions fell, in the case of Donetsk Oblast and Luhansk Oblast this decline was radical in nature. The average for the other regions with a loss amounted to 5.7 percentage point. Only in three districts an increase in the number of employed was recorded, i.e. Ivano-Frankivsk Oblast, Sumy Oblast and Kharkiv Oblast, which may be due to internal labor migration from the east of the country. The indicated causes caused a significant spatial diversity of the number of employees. This is confirmed by the statistically calculated standard deviation(s), the value of which for the indicator used in 2010 was 155.2 and in 2017 already 426.6. The more regionally individualized situation concerns the number of unemployed per 10,000 residents in the group of 15-70 years. In this case, in 9 regions a decrease in the number of unemployed was noted, taking into account the aforementioned specificity of the measurement, while in the remaining 16 there was an increase in the number of unemployed. Importantly, their differently measured standard deviation increased from 52.4 to 81.5 but it is definitely smaller than in the previous indicator, which may indicate a similar scale of the problem, although different scenarios for its solution.

To regions with a drop in the number of unemployed, apart from Donetsk Oblast and Luhansk Oblast, where the recorded decline was due to a very difficult socio-political situation and should not be assessed in terms of economic success, include districts which, due to e.g. its border location Chernivtsi Oblast and Lviv Oblast, also possible Sumy Oblast or in the sphere of direct influence of the capital of the country Kiev are theoretically more likely to alleviate the phenomenon of unemployment. This group also includes districts with significant economic potential, which is still one of the regional development locomotives, i.e. Kharkiv Oblast. Districts with the highest unemployment rate per 10,000 residents are located in the southeast of Ukraine creating a clear concentration. The only exception in this group is Volyn Oblast, which is located in Western Ukraine. The increase in unemployment in most Ukrainian districts is a consequence of the country's macroeconomic situation, but also results from quantitative and qualitative social resources whose internal drainage (domestic, to urban agglomeration) and external drainage (foreign, to other countries) 
continues and becomes a serious threat to local and regional development.

The main way by which the government tries to stop the outflow of employees is to raise the minimum wage. In the examined period, it was raised abruptly, but although in percentage terms it is a significant result, however its real effect is negligible. After taking into account the variable exchange rate of hryvnia (UAH) to the US dollar (USD) in the period 2010-2017, it turned out that the increases made were apparent and the average salary increase was $-2 \%$ (tab. 5). On a regional scale, the variation in the average nominal wage has decreased from USD 221,8 to USD 209,1 which may indicate the "employee labor market" regardless of the place of work. In addition, in only three districts: Volyn Oblast,
Zakarpattia Oblast and Zaporizhia Oblast there is a real $3 \%$ salary increase. In the remaining seven, there is stagnation, and in the next 15 districts a real, we encounter several percent decrease in salaries. The exception is Luhansk Oblast, where the drop in salaries was over $20 \%$.

The conducted analysis proves that the announced increases do not bring the expected effect, and Ukraine is still among the European leaders in the countries with the lowest earnings, and this is the main stimulus for economic emigration of Ukrainians (tab. 6).

The migratory pressure examined in 2017, although ubiquitous, is not as felt the same way in every district. Districts in which migration moods (both those already realized and those declared in the near

Tab. 5. Employed and unemployed (aged 15-70) and average wages in Ukraine ${ }^{1}$ - regional approach

\begin{tabular}{|c|c|c|c|c|c|c|c|c|c|}
\hline \multirow{3}{*}{$\begin{array}{l}\text { Oblasts } \\
\text { of Ukraine }\end{array}$} & \multicolumn{9}{|c|}{ Years } \\
\hline & 2010 & 2017 & $2010=100$ & 2010 & 2017 & $2010=100$ & 2010 & 2017 & $\begin{array}{c}\text { relative } \\
\text { increment }\end{array}$ \\
\hline & \multicolumn{3}{|c|}{$\begin{array}{l}\text { Employed persons } \\
\text { for } 10 \text { thous. residents }\end{array}$} & \multicolumn{3}{|c|}{$\begin{array}{c}\text { Unemployed } \\
\text { for } 10 \text { thous. residents }\end{array}$} & \multicolumn{3}{|c|}{$\begin{array}{l}\text { Average nominal wage }{ }^{2} \\
\text { [in USD] }\end{array}$} \\
\hline Cherkasy & 4375.22 & 4247.92 & 97.1 & 483.30 & 485.10 & 100.4 & 229.7 & 226.4 & 0.99 \\
\hline Chernihiv & 4347.78 & 4177.13 & 96.1 & 508.04 & 524.47 & 103.2 & 214.1 & 211.2 & 0.99 \\
\hline Chernivtsi & 4231.11 & 4183.30 & 98.9 & 393.90 & 383.81 & 97.4 & 221.8 & 210.6 & 0.95 \\
\hline Dnipropetrovsk & 4610.84 & 4304.67 & 93.4 & 351.97 & 399.86 & 113.6 & 296.5 & 260.0 & 0.88 \\
\hline Donetsk & 4459.73 & 1748.14 & 39.2 & 411.19 & 298.30 & 72.5 & 319.0 & 290.9 & 0.91 \\
\hline Ivano-Frankivsk & 3840.61 & 4058.09 & 105.7 & 344.01 & 376.77 & 109.5 & 241.2 & 227.6 & 0.94 \\
\hline Kharkiv & 4599.70 & 4614.32 & 100.3 & 355.33 & 298.44 & 84.0 & 257.8 & 233.9 & 0.91 \\
\hline Kherson & 4479.67 & 4223.57 & 94.3 & 422.49 & 525.32 & 124.3 & 216.9 & 218.9 & 1.01 \\
\hline Khmelnytskyi & 4360.38 & 4048.94 & 92.9 & 412.31 & 393.91 & 95.5 & 223.5 & 222.5 & 1.00 \\
\hline Kiev & 4407.42 & 4224.52 & 95.9 & 347.17 & 295.85 & 85.2 & 287.2 & 269.3 & 0.94 \\
\hline Kirovohrad & 4249.08 & 3940.39 & 92.7 & 416.83 & 550.07 & 132.0 & 227.2 & 217.0 & 0.96 \\
\hline Luhansk & 4413.99 & 1347.45 & 30.5 & 342.11 & 268.94 & 78.6 & 284.2 & 219.6 & 0.77 \\
\hline Lviv & 4308.16 & 4154.00 & 96.4 & 366.51 & 339.18 & 92.5 & 242.9 & 239.5 & 0.99 \\
\hline Mykolaiv & 4523.57 & 4290.63 & 94.9 & 416.37 & 493.29 & 118.5 & 265.6 & 251.4 & 0.95 \\
\hline Odessa & 4374.62 & 4140.03 & 94.6 & 284.80 & 323.95 & 113.7 & 256.1 & 245.1 & 0.96 \\
\hline Poltava & 4316.89 & 4066.97 & 94.2 & 463.29 & 553.82 & 119.5 & 263.1 & 245.4 & 0.93 \\
\hline Rivne & 4088.23 & 3965.03 & 97.0 & 527.51 & 517.81 & 98.2 & 245.3 & 225.3 & 0.92 \\
\hline Sumy & 4259.64 & 4399.22 & 103.3 & 507.39 & 438.64 & 86.5 & 233.5 & 222.8 & 0.95 \\
\hline Ternopil & 3968.92 & 3792.60 & 95.6 & 467.47 & 512.21 & 109.6 & 207.6 & 208.1 & 1.00 \\
\hline Vinnytsia & 4217.46 & 4067.12 & 96.4 & 467.12 & 485.47 & 103.9 & 223.0 & 229.3 & 1.03 \\
\hline Volyn & 4176.37 & 3524.46 & 84.4 & 390.09 & 501.71 & 128.6 & 211.8 & 219.1 & 1.03 \\
\hline Zakarpattia & 4266.95 & 3944.67 & 92.4 & 404.39 & 462.58 & 114.4 & 231.0 & 238.1 & 1.03 \\
\hline Zaporizhia & 4573.42 & 4176.60 & 91.3 & 370.55 & 500.24 & 135.0 & 273.7 & 257.1 & 0.94 \\
\hline Zhytomyr & 4366.42 & 4147.04 & 95.0 & 473.82 & 503.56 & 106.3 & 223.4 & 218.7 & 0.98 \\
\hline m. Kiev & 4956.43 & 4623.58 & 93.3 & 306.79 & 344.52 & 112.3 & 429.4 & 417.2 & 0.97 \\
\hline
\end{tabular}

1 - due to the lack of data, Crimea and Sevastopol are not included in the list;

2 - at the average annual USD exchange rate.

Source: Statističnij..., 2018. 
Tab. 6. The scale of economic emigration by regions of Ukraine. As of December 2017

\begin{tabular}{|c|c|c|c|}
\hline Ranking & $\begin{array}{l}\text { Oblasts } \\
\text { of Ukraine }\end{array}$ & $\begin{array}{l}\text { Share of actual and declared emigrants } \\
\text { in the entire population } \\
\text { [in \%] }\end{array}$ & $\begin{array}{l}\text { Share in the total number of economic } \\
\text { emigrants } \\
\text { [in \%] }\end{array}$ \\
\hline 1. & Ternopil & 23 & 6 \\
\hline 2. & Zakarpattia & 21 & 7 \\
\hline 3. & Rivne & 18 & 8 \\
\hline 4. & Khmelnytskyi & 17 & 3 \\
\hline 5. & Cherkasy & 16 & 5 \\
\hline 5. & Chernihiv & 16 & 3 \\
\hline 5. & Ivano-Frankivsk & 16 & 6 \\
\hline 6. & Kiev & 15 & 3 \\
\hline 6. & Lviv & 15 & 6 \\
\hline 6. & Poltava & 15 & 7 \\
\hline 7. & Sumy & 14 & 2 \\
\hline 7. & Vinnytsia & 14 & 5 \\
\hline 8. & Kirovohrad & 13 & 4 \\
\hline 9. & Luhansk & 12 & 2 \\
\hline 10. & Zaporizhia & 11 & 3 \\
\hline 10. & Zhytomyr & 11 & 5 \\
\hline 11. & Kharkiv & 10 & 5 \\
\hline 11. & Dnipropetrovsk & 10 & 2 \\
\hline 11. & Volyn & 10 & 1 \\
\hline 12. & m. Kiev & 9 & 3 \\
\hline 12. & Kherson & 9 & 4 \\
\hline 13. & Odessa & 8 & 1 \\
\hline 14. & Donetsk & 6 & 3 \\
\hline 14. & Mykolaiv & 6 & 3 \\
\hline 15. & Chernivtsi & 5 & 2 \\
\hline
\end{tabular}

Source: Prajsnar, 2018.

future) are most popular are located in the western part of the country. Next, although with a slight loss, are districts located in the central Ukraine and finally with the eastern part of the country. The location rent is not always important, but a more significant stimulus towards migration in terms of attitudes, intentions and entrepreneurial activity of the local community, and perhaps also a cultural factor determining local identity and awareness. It is worth emphasizing, however, that slight differences in the results obtained do not allow for building far-reaching conclusions. To sum up, Ukrainians still go abroad to work, because domestic business cannot raise the salary enough to make it attractive. It is also worth emphasizing the non-monetary factors of travel such as social conditions of stay and work, quality of the environment, willingness to change the environment or family pressure of people who left earlier.

\section{Specificity of the Ukrainian labor market (current situation)}

From the beginning of 2019, the Ukrainian labor market is experiencing a huge shortage of qualified employees who are being encouraged to take up work with raised wages. The market is lacking in particular accountants, doctors, teachers, lawyers, pharmacists, economists, as well as engineers from various professions. At the same time, approximately $75 \%$ of the unemployed Ukrainians are people with higher education. Therefore, the question arises about adjusting the educational offer at a higher level to the needs of national and regional labor markets. For example, the problem of the lack of business schools that would educate managerial staff is often signaled. Those who offer such education are usually of poor level. Business owners complain that there are no candidates for the management team for the positions of directors they could employ, even with 
salaries of 2 thous. USD. Everything indicates that this is a serious structural problem, which unfortunately requires time to be solved by the education sector service providers, who should adopt their activities to the changing economic reality in the mental, organizational and marketing dimension. A good example of a change for the better can be the fact that in 2019, 928 people received coupons for training and advanced education, but on a national scale this should be considered a far insufficient level (Pervak, 2019; Śmietana, 2019).

There is also a shortage of qualified production workers in such professions as seamstress, locksmith, bricklayer, carpenter, etc. Also employees in the service sector are sought after, especially salesmen, bodyguards, nurses, bakers, bartenders, hairdressers, social workers etc. The problem is not solved by relatively high salaries from 10 to even 20 thous. UAH. Candidates often do not even have basic knowledge in a given profession. Job placement has developed due to difficulties in reaching employees and recruiting them on a massive scale. Their main direction of activity is not seeking free resources, especially in peripheral areas or activities aimed at reorienting jobs that are so needed in places of structural unemployment, but relatively simpler and more cost-effective recruitment of economic migrants, sometimes in an unreliable manner. It would be much more appropriate to work with school and university graduates to prepare them theoretically and practically for entering the labor market, choosing a profession in line with predispositions, perhaps also gaining first professional experience through a system of apprenticeships and professional internships and making them aware of the necessity of education throughout their lives in order to increase own competitiveness on the labor market. Promoting new forms of employment, such as a freelancer, or even new professions such as an eteacher, also requires more attention. Of course, this requires adequate technical facilities and financial resources, but the question about the justification of such actions from the point of view of the development of the information society seems to be rhetorical (Rinok pracì..., 2019).

At the beginning of 2019, over 235000 vacancies were reported. A lot of these concerned the industry, then trade, and finally the agricultural sector. The average salary also increased and reached the level of 6.1 thous. UAH, but what is more important, is that in most of the proposed jobs it was higher. This mainly concerns the largest urban agglomerations of Ukraine, and above all the Kiev agglomeration. The number of registered unemployed amounted to over 365 thous. most of whom were women.
According to official statistics, over 3 million Ukrainian citizens were permanently resident abroad, but an average of 7 to 10 million may participate annually in the entire migration process. Of course, this number is not constant, and its changes are mainly caused by seasonal factors (Kulchytska, Minich (eds.), 2019; Šutka, 2019).

Finally, the impact of the political factor on the labor market should be emphasized. It should be remembered that in a situation of uncertainty, business weakens and goes into a state of anticipation, which must lead to a slowdown and sometimes suspension of operations. Therefore, one should be very cautious about statements and decisions, because it may quickly turn out that they will have their market consequences, including changes in the labor market. This seemingly obvious is not always respected, which may indicate the weakness of political elites.

\section{Conclusion}

To sum up, the labor market is an extremely complex system, and thus requiring large and constant attention. It is the result of the macroeconomic situation of the country, the socio-cultural and demographic condition of the society, and political activities. Due to its sensitivity (which is determined by the human factor) it is relatively easy to weaken it and upset the balance between the demand and supply of labor.

The content presented in the article inclines to the conclusion that the Ukrainian labor market is facing both quantitative and qualitative problems in both national and regional terms. On the one hand, there is a shortage of hands to work, and on the other, there is still a large percentage of people out of work. This clear dissonance is related to the mismatch of the structure of the unemployed to the structure of jobs. The adaptation of these two structures takes time and is in principle impossible to achieve in the short term. Therefore, the level of remuneration was adopted as the main determining factor. The neglect at its level, however, is so large that despite the actions carried out this does not bring the expected result. In addition, the modern employees, especially those who have already experienced work abroad, do not reduce their requirements and expectations to the payroll factor regardless of origin, sex, age or place of residence (McCormick, Sheppard, 1992).

In the period 2010-2017, which in Ukraine can be considered a politically turbulent, functioning of the labor market was determined by the continued economic transformation and transition to the rules of the market economy, which in the Ukrainian version is still in a phase of transformation shock. The 
shock that does not allow her to escape the lack of a clear, consistent social and economic vision of the country and the lack of proper power elites (at all levels) prepared in terms of content and mentality for change. Hence, often visible ad hoc activities on the labor market, which is illustrated by unfavorable indicators illustrating its functioning in the form of the number of the unemployed, professionally active and employed. Their changes were undoubtedly influenced by both political changes, especially the turn of 2013-2014, which is clearly indicated in the results presented, as well as the equally dangerous very bad demographic situation of the country. Its effects are not very visible in the short-term perspective, but very severe in the long run. When solving the first of these problems on an ad hoc basis, Ukrainians should pay much more attention to the second one, not only in national terms, but also in regional terms, as these sometimes differ significantly from each other.

\section{References}

Batchenko L., Dielini M., 2011, Labour market in Ukraine: State and development prospects, Actual Problems of Economics, 120(6), 157-163.

Campling L., Miyamura S., Pattenden J., Selwyn B., 2016, Class dynamics of development: a methodological note, Third World Quarterly, 37(10), 1745-1767. doi: 10.1080/01436597.2016.1200440

Cartelier J., 2017, About waged labour: From monetary subordination to exploitation, Economic Thought, 6(2), 27-36.

Czaplińska A., Kibych I., 2019, Eksport drewna z Ukrainy na tle rosnącego deficytu surowcowego w przemyśle drzewnym UE (Eng. Export of timber from Ukraine against the background of a growing commodity deficit in the EU wood industry). Prace Komisji Geografii Przemysłu Polskiego Towarzystwa Geograficznego, 33(4), (in press).

Czapliński P., Kibych I., 2017, Postawy abiturientów wobec rynku pracy: Szczecin i Czerniowce - studium przypadku (Eng. Attitudes of High School Graduates toward the Labour Market. Szczecin and Chernivtsi - Case Study), Przedsiębiorczość-Edukacja, 13, 405-416. doi: 10.24917/20833296.13.30

Dluhopolskyi O., Zatonatska T., Lvova I., Klapkiv Y., 2019, Regulations for Returning Labour Migrants to Ukraine: International Background and National Limitations, Comparative Economic Research, 22(3), 45-64. doi: 10.2478/cer-20190022

Fichter M., 2005, The German: Way still treading the path of institutionalized labor relations? [in:] S. Beck, F. Klobes, C. Scherrer, (eds.), Surviving globalization?: Perspectives for the German economic model, University of Kassel, Kassel, 93-110.

Fritz V., 2005, New divisions in Europe? East-East divergence and the influence of European Union enlargement,
Journal of International Relations and Development, 8(2), 192-217.

Hollinshead G., 2019, Global value chains in international knowledge work: networks, stratifications and labour markets, Global Networks, (in press). doi: 10.1111/ glob. 12253

Kulchytska K., Minich R. (eds.), 2019, Myths and facts about ukrainian labour migration to the Visegrad group, 2019, Europe without Barriers (Ukraine), https://europewb.org. ua/wp-content/uploads/2019/05/Giude-EN-fin.pdf (accessed 30 September 2019).

Lehmann H., Muravyev A., Zimmermann K.F., 2012, The Ukrainian longitudinal monitoring: towards a better understanding of labor markets in transition, IZA Journal of Labor and Development, 1(1), 9.

Markina I., Sharkova A., Barna M., 2018, Entrepreneurship in the shadow economy: The case study of Russia and Ukraine, International Journal of Entrepreneurship, 22(3), 1939-4675-22-3-158.

Markova E., Paraskevopoulou A., McKay S., 2019, Treading lightly: Regularised migrant workers in Europe, Migration Letters, 16(3), 451-461.

McCormick B., Sheppard S., 1992, A model of regional contraction and unemployment, Economic Journal, 102(411), 366-377.

Migration and migrant population statistics, Eurostat, https://ec.europa.eu/eurostat/statistics-explained/index.php?title=Migration_and_migrant_population_ statistics\&oldid=331044 (accessed 30 September 2019).

Migration in Ukraine: facts and figures, 2016, IOM Mission in Ukraine, Kyiv.

Moskalenko K.S., Zaporozhets Ju.V., 2018, The state of the labour market of Ukraine, Young Scientist, 5(57), 730-734.

Niemets L., Sehida K., Kravchenko K., Telebienieva I., Peresadko V., 2018, Trends forming policentric model of spatial development and implementation of the European experience for Ukraine, [in:] Proceedings of the 32nd International Business Information Management Association Conference. IBIMA 2018 - Vision 2020: Sustainable Economic Development and Application of Innovation Management from Regional expansion to Global Growth 2018, IBIMA, Seville, 362-374.

Oliskevych M., 2015, Hysteresis, structural shocks and common trends in labor market: consequence for Ukraine, Ikonomicheski Izsledvania, 24(4), 120-137.

Oliskevych M., Tokarchuk V., 2018, Dynamic modelling of nonlinearities in the behaviour of labour market indicators in Ukraine and Poland, Economic Annals-XXI, 169(12), 35-39. doi: 10.21003/ea.V169-07

Pervak G., 2019, Odin slûsar na sìm vakansij: ŝo ne tak ìz profosvitoû v Ukraïni (Eng. One locksmith for seven jobs: what's wrong with the trade union in Ukraine), https://censor. net.ua/ua/resonance/3118923/odyn_slyusar_na_sim_ vakansiyi_scho_ne_tak_iz_profosvitoyu_v_ukrayini (accessed 30 September 2019).

Prajsnar A., 2018, Ukraina zostanie bez pracowników? Deficyt rąk do pracy się pogłębia (Eng. Ukraine will be without employees? The deficit of hands for work is deepening), https://forsal.pl/galerie/1196506,duze-zdjecie,1,ukraina- 
zostanie-bez-pracownikow-deficyt-rak-do-pracy-sie-poglebia.html (accessed 30 September 2019).

Registration of employers' declarations of intention to entrust work to a foreigner, Ministry of Family, Labor and Social Policy of the Republic of Poland, https://www.gov.pl/ web/rodzina/statystyka-dotyczaca-zatrudniania-cudzoziemcow (accessed 30 September 2019).

Rinok pracì u I kvartalì 2019 roku: robotodavcì vzâli pauzu, a pošukačìperekvalifikovuût'sâ (Eng. Labor market in Q1 2019: employers take a break and job seekers are retrained), HeadHunter Україна, https://hh.ua/article/24483 (accessed 30 September 2019).

Ryndzak O., 2019, Evaluation of a population's migration potential as an important component of migration policy, Economies, 7(3), 72. doi: 10.3390/economies7030072

Sadova U., 2010, Migration risks in the context of social-economic transformations of Ukraine, Economics and Sociology, 3(1a), 89-98.

Śmietana K., 2019, Cudzoziemcy uratuja budowy? Brakuje już ponad 100 tys. pracowników, a będzie jeszcze gorzej (Eng. Foreigners will save the construction sites? There is already a shortage of over 100,000 workers and it will be even worse), https://serwisy.gazetaprawna.pl/praca-i-kariera/artykuly/1429618,budowlanka-brak-pracownikowukraincy.html (accessed 30 September 2019).

Statističnij ŝoričnik za 2017 rìk (Eng. Statistical Yearbook of Ukraine 2017), 2018, Deržavna služba statistiki Ukraïni, Kiïv.

Šutka N., 2019, Rinok praci s'ogodnì i do čogo tut vibori (Eng. The labor market today and what is the election here), https:// zik.ua/news/2019/04/15/rynok_pratsi_sogodni_i_do_ chogo_tut_vybory_1552011 (accessed 30 September 2019).

Zappalà S., Massei F., 2011, Psycho-social factors and innovativeness in a sample of small enterprises, Psicologia Sociale, 6(1), 51-70. 